\title{
E-Government Adoption in Tunisia Extending Technology Acceptance Model
}

Wadie Nasri, Université de Gabès, Gabès, Tunisia

\begin{abstract}
The purpose of this study is to examine the factors which affect e-government services adoption of Tunisian's citizens by using a technology acceptance model (TAM). The proposed conceptual model was extended by adding social influence, awareness, and quality of internet connection. The proposed model was empirically tested using survey data provided by 150 respondents and was analyzed using a structural equation model (SEM). The findings indicate that the proposed model is a stable model and a good explanatory. Perceived usefulness is predicted mutually by social influence and awareness. Moreover, perceived ease of use is predicted by quality of internet connection. This study contributes to the literature by providing a new research model for understanding e-government services adoption in Tunisia and its findings provide useful guidelines to develop policies and strategies to increase the adoption of e-government services.
\end{abstract}

\section{KEYWORDS}

Adoption, Attitude, Awareness, Citizen, E-Government, Perceived Ease of Use, Perceived Usefulness, Quality of Connection Internet, Social Influence, Tunisian

\section{INTRODUCTION}

Public service is one of the areas which has been evolved significantly by developments in Information and Communication Technology (ICT) field. E-government is defined as "the use of (ICT) in general and the utilisation of Internet in particular as a tool to achieve better government (OECD, 2003). Better government means delivering public services and processing internal works in the government in a much more convenient, customer-oriented, and cost-effective way (Song, 2004)". Simply, e-government aims at accomplishing a government's daily administrative activities and providing an easier way for the government to communicate with external entities such as citizens and businesses with the use of (ICT) (Ramlah et al, 2010).

Titah and Barki, (2006) noted that e-government is a multi-faceted concept that can involve four types of stakeholders (government, citizens, businesses, and employees). In general, Fang (2002) classified e-government into eight categories as follows: (1) Government-to-Citizen (G2C), (2) Citizen-to-Government (C2G), (3) Government-to-Business (G2B), (4) Business-to-Government (B2G), (5) Government-to-Employee (G2E), (6) Government-to-Government (G2G), (7) Governmentto-Nonprofit (G2N), (8) Nonprofit-to-Government (N2G). The government aims to save time and financial sources for the businesses, citizens and public organisations and to increase transparency, 
reliability, accountability and participation by providing services in electronic environment (Sebetci, 2015). This research focuses mainly on the G2C services function and Internet websites were chosen as the main channel used to deliver e-government services to citizens. One of the key problems for the successful implementation of e-Government services is a lack of awareness of the potential factors that help citizens to adopt and use e-Governments services and the ability of the government to implement e-Government to match the needs of the citizen and web visitor (Gant, 2008; Prattipati, 2003).

The rapid growth in the use of the internet in Tunisia country (7,898,534 Internet users in 30 June 2019 based on data from Internet Word Stats) has increased pressure on the government to administer to citizens needs via this new medium. The development of e-government in Tunisia was initiated in 2002. The E-Government unit was established as a unit in presidency of the government in order to coordinate and monitor implementation of decisions, recommendations and projects under the e-government program, employ different projects correlated to e-government, to make available technical recommendations and guidelines for the implementation of such projects, and to set standards for software and infrastructure in the field. After a set of explorations in IT, some central ministries started to introduce their own networks. For example, the national government portal (http://www. tunisie.gov.tn/) provides a most used services' on the home page that provides quick access for citizens to information on service regarding the ministry of social business transport education, ministry of transportation, ministry of finance, ministry of social affairs, ministry of education. Many government services are used $100 \%$ on line such as: university orientation, university registration, tax declaration, public job candidacy and e-payment.

For successful implementation of e-government services, citizens' willingness to adopt e-government is considered as the most dominating aspect. Thus, user's acceptance of e-government is regarded as one of the success criteria for e-government (Hwang et al., 2004). To address this aspect, research work aims to identify the factors that may influence citizens to utilize e-government websites in their daily life to interact with the government in Tunisia. In order to implement the concept of e-government adoption, there are various adoption theories and models which are proposed to explain the acceptance of e-government services. In the current study, Technology Acceptance Model (TAM) (Davis, 1989; Davis et al., 1989) was enriched with social influence, awareness and quality of internet connection factors to explore the determinants of e-government adoption of Tunisian's citizens.

This research is organized as follows: first, a review of literature on the TAM (Davis, 1989; Davis et al., 1989), social influence, awareness, and quality of internet connection based on which the model and hypotheses are formulated to predict citizen' intention to adopt e-government services, is presented. Second, research methodology and extended model is tested. Third, findings of the analysis are presented. Finally, discussion of the empirical findings and the article concludes with theoretical and managerial implications, limitations that can be addressed in future research.

\section{LITERATURE REVIEW}

\section{Theoretical Framework}

In literature, there are various models have been developed to explain the acceptance and use of information systems. The Technology Acceptance Model (TAM) (Davis, 1989; Davis et al., 1989), Theory of Reasoned Action (TRA) (), Theory of Planned Behaviour (TPB) (Ajzen, 1991), Innovation and Diffusion Theory (IDT) (Rogers, 1995) and the Unified Theory of Acceptance and Use of Technology (UTAUT) (Venkatesh et al., 2003) models have been developed to determine the factors that affect the use of information technology.

Among the different models that have been proposed, the Technology Acceptance Model (TAM) (Davis, 1989; Davis et al., 1989) adapted from the Theory of Reasoned Action (TRA) (Fishbein and Ajzen, 1975) and the Theory of Planned Behaviour (TBA) (Ajzen, 1991), is 
considered as an effective and valid model that explains an individual's adoption of information systems (Davis, 1989; Davis et al., 1989).

The constructs of TAM that affect technology use are external variables (external stimulus), perceived usefulness and perceived ease of use (cognitive response), behavioral intention, and actual usage (behaviour) (Davis et al, 1996). The fundamental idea of the Technology Acceptance Model is that perceived usefulness and perceived ease of use influence the users' intention to use information technology either directly or mediating via attitude towards the behaviour, leading to actual usage of the system. Attitude towards and behavioural intention are common with the Theory of Reasoned Action and the Theory of Planned Behaviour. Perceived ease of use has a strong influence on attitude through perceived usefulness, but also directly.

Perceived usefulness has a strong direct influence via both attitude and behavioural intention. Perceived usefulness was defined as "the degree to which a person believes that using a particular system would enhance his or her job performance" (Davis, 1989). "A system high in perceived usefulness, in turn, is one for which a user believes in the existence of a positive use-performance relationship". Perceived ease of use is defined "the degree to which a person believes that using a particular system would enhance his or her job performance" (Davis, 1989). Therefore, Davis et al. (1989) articulated that perceived ease of use could contribute to the behavioural intention to use technology directly or indirectly by facilitating the role of perceived usefulness.

In information system literature, TAM has been used in very different settings, to test the acceptance of computer technology (Davis et al., 1989), online shopping (Gefen et al., 2000), e-commerce (Pavlou, 2003), mobile computing (Wu et al., 2007), banking adoption (Martins et al., 2014) and e-Government services (Carter and Belanger, 2005).

Our review of the literature on e-Government adoption revealed that TAM was the model that was utilized most often in the literature (Gefen et al, 2002). For example, developing a TAM based model, Carter and Belanger (2005) compared e-government acceptance in UK and USA. Hu et al. (2011) extended TAM to investigate technology acceptance levels for a certain mobile technology. Lin et al. (2011) developed a TAM based model to analyse the effect of TAM and e-government initiatives on e-government applications in Gambia. Sebetci (2006) extended (TAM)-based model for a mandatory system in Turkish public institutions. The constructs of the extended model are mandatory use, management support, training support, attitude, perceived usefulness, perceived ease of use and use. Ozkan and Kanat (2011) developed a model based on TRA and TAM regarding the use of government-to-citizen (G2C) e-government services to determine students' loans service system adoption behaviours of Turkish university students. These models are generally extended by adding various variables to TAM due to the multidisciplinary structure of the field.

The original TAM was revised by leaving attitude from the model, as empirical validation proved that intention to use is only partly mediated by attitude (Davis and Venkatesh, 1996). As TAM is used as the base model, we need to test the following TAM hypotheses in the context of e-government services adoption:

H1: Citizen's attitude has a significant effect on user's intention to adopt e-government services.

H2: Perceived usefulness has a significant effect on citizen's intention to adopt e-government services.

H3: Perceived usefulness has a significant effect on user's attitude towards adoption e-government services.

H4: Perceived ease of use has a significant effect on user's perceived usefulness to adopt e-government services.

H5: Perceived ease of use has a significant effect on citizen's attitude to adopt e-government services.

In this research we proposed another three constructs that should be embedded into the model to better understand the citizen acceptance of e-government services in Tunisia social influence, awareness and quality of Internet connexion. 


\section{Social Influence}

Social influence (SI) is defined as "the extent to which an individual perceives that important others believe he or she should apply the new system" (Venkatesh et al. 2003). Likewise et al, (2002) suggested social influence cannot be ignored in any adoption model because of their contribution to adoption behaviour. Social norms have been validated in studies which provide empirical evidence of the significant effect of social influence on the intention to use internet banking (Shih and Fang, 2004). Thus, social influence is hypothesized as:

H6: Social influence has a significant effect on user's perceived usefulness to adopt e-government services.

\section{E-Government Services Awareness}

In this research study, the construct awareness (AW) refers to the information that the user possesses regarding availability of e-government services, range of services, process of signing up and benefits and risks involved. In this setting, Rogers and Shoemaker (1971) stressed on the fact that consumers undergo a process of knowledge, belief, decision making and confirmation before adopting a product or service. Adoption of e-government services will be determined by the level of information that a citizen has about e-government and its likely benefits. Therefore, awareness is an important element that needs to be considered before adopting any innovative products (Sathye, 1999). Hence, it is hypothesized that:

H7: E-government services awareness has a significant effect on user's perceived usefulness to adopt e-government services.

\section{Quality of the Internet Connection}

The quality of internet (QI) banking, defined in terms of speed and continuity, can influence user's perception of the ease of use. A low-quality connection can make completion of banking tasks difficult and lead to uncertainty regarding the status of transaction. This can adversely impact the degree of PEOU and affect the adoption of internet banking. On the other hand, a better internet service can enhance the user's perception of ease of use and make the user more inclined to use internet banking (Sathye, 1999). Hence, it is hypothesized that (Figure 1):

H8: Quality of the internet connection has a significant effect on user's perceived ease of use to adopt e-government services.

\section{METHODOLOGY}

\section{Data Collection}

This study adopts the TAM model to investigate the intention to use e-government services in Tunisia. The population of this research is Tunisian citizens who are internet users with or without experience of using e-government services. A structured questionnaire was designed, distributed, and collected in order to study the factors that affect citizens' adoption of e-government in Tunisia. The survey questionnaire is divided into two parts. The first part of the questionnaire is inquired demographic details of the respondents such as age, gender and education level. While, the second part of the questionnaire holds measurement items of each of the seven constructs of the present study. Therefore, items selected for the constructs were mainly adapted from prior studies to ensure content validity. Perceived usefulness, perceived ease of use and social influence were adapted from Davis 
Figure 1. Theoretical model

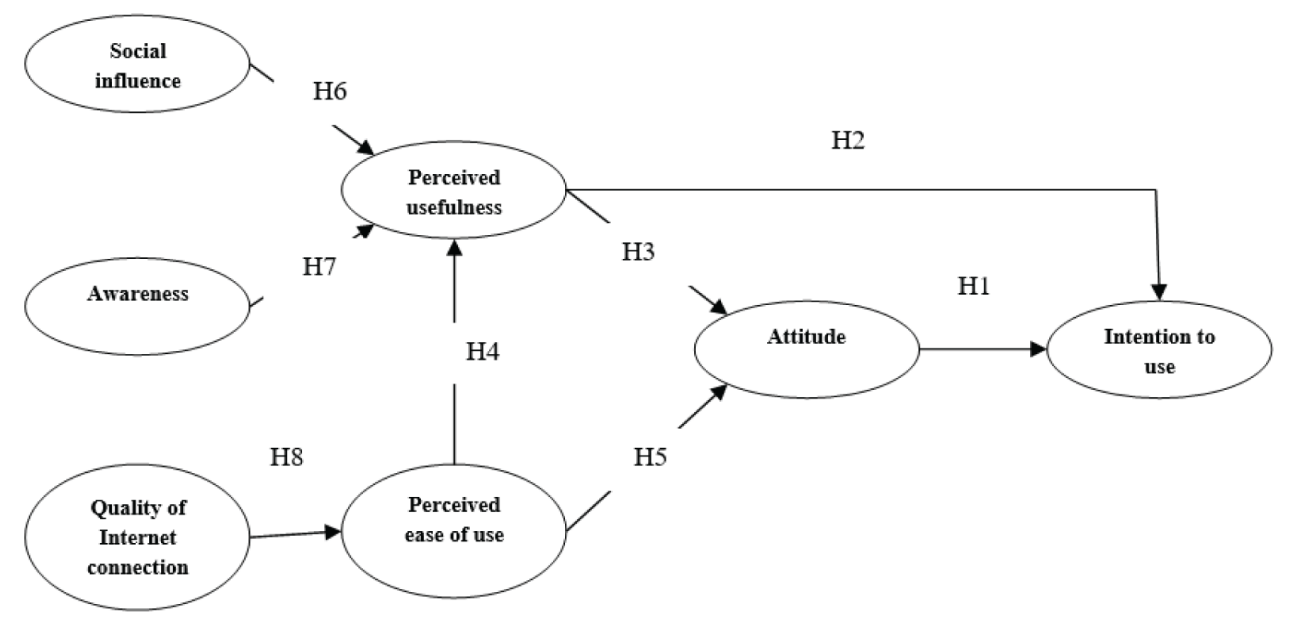

et al. (1989). Behavioral intention and attitude towards e-government were adapted from Venkatesh et al. (2012). The quality of connexion internet was adapted from Pikkarainen et al. (2004) and the e-government services awareness scale was adapted from Sathye, (1999).

All items were measured using a five-point Likert scale, with the anchors being "strongly disagree" and "strongly agree.", with the responses rated as follows: 1 "as strongly disagree", 2 as "disagree", 3 as "somewhat agree", 4 as "agree", and 5 as "strongly agree". The questionnaire was originally developed in English, and subsequently translated into Arabic by a university graduate. The questionnaire was distributed among the citizens via e-mail along with the web link. A total of 150 useful responses were collected, resulting into a response rate of 65 per cent (150 out of 230). The sociodemographic details of the respondents are summarized in Table 1.

Table 1. Demographic profile of the respondents

\begin{tabular}{|c|c|c|c|}
\hline Measures & Items & Frequency & Percentage (\%) \\
\hline \multirow{2}{*}{ Gender } & Male & 93 & 62.00 \\
\hline & Female & 57 & 38.00 \\
\hline \multirow{6}{*}{ Age } & $20-24$ & 12 & 8.00 \\
\hline & $25-29$ & 12 & 8.00 \\
\hline & $30-34$ & 52 & 34.66 \\
\hline & $35-39$ & 48 & 32.00 \\
\hline & $40-50$ & 14 & 9.33 \\
\hline & $>50$ & 12 & 8.00 \\
\hline \multirow{3}{*}{ Education } & Bachelor's & 40 & 26.66 \\
\hline & Master's & 35 & 23.33 \\
\hline & Doctorate & 75 & 50.00 \\
\hline \multirow{4}{*}{ Years using internet } & $<$ year & 8 & 5.33 \\
\hline & $3-4$ years & 22 & 14.66 \\
\hline & $3-5$ years & 34 & 22.66 \\
\hline & $>5$ years & 86 & 57.33 \\
\hline
\end{tabular}




\section{Measurement Model}

A confirmatory factor analysis (CFA) was used to test the measurement of the proposed model. Based on the two step recommended by Anderson and Gerbing (1988), we first analyzed the measurement model to test the reliability and validity of the instrument, then we analyzed the structural model to test our research hypotheses.

First, we conducted a CFA to examine the reliability and validities including convergent validity and discriminant validity. Convergent validity is assessed with three tests recommended by Anderson and Gerbing (1988). Table 2 lists the standardized loadings, Cronbach's alpha reliability, and varianceextracted estimates. As indicated in Table 2 and Table 3, most item loadings were larger than 0.5 (expect AW2 was eliminated, due to lower standardised outer loading recommendation by Churchill (1979). All Cronbach's alpha and AVE exceeded the recommended threshold values of 0.7 and 0.5 respectively (Bagozzi and Yi, 1988; Gefen et al., 2000; Nunnally, 1978). This showed good convergent validity and reliability of the scales.

Additionally, discriminant validity is said to be achieved if square roots of average variance extracted (AVE) which reside in diagonal cells (Table 3) are greater than the inter-factor correlations between constructs, which are under the diagonal cells (Hair et al., 2010). Therefore, it was concluded that there is enough confidence in the discriminate validity of the measures and their corresponding constructs.

\section{Structural Model}

CFA using LISREL 8.5 was conducted to test our measurement model. The overall model fit was assessed using eight goodness-of-fit indices: Absolute Fit Measures $\left(\chi^{2}\right) / \mathrm{dl}$, Goodness of Fit Index (GFI), Root Mean Square Error of Approximation (RMSEA), Root Mean Square Residual (RMR), Incremental Fit Measures ((Normed Fit Index (NFI), Non Normed Fit Index (NNFI), Comparative Fit Index (CFI)), Incremented Fit Measures (IFI)) and Parsimony Fit Measures (Adjusted Goodness of Fit Index (AGFI), Parsimonious Normed Fit Index (PNFI)). The results of these indices, along with their recommended values for the common model fit, are shown in Table 4. Having established the relative adequacy of the model's fit, it is appropriate to examine individual path coefficients corresponding to our hypotheses. This analysis is presented in Table 5.

\section{DISCUSSION}

This study explains the fundamental argument that intention to adopt e-government services are highly influenced by respondents' attitude toward e-government services and these attitudes are influenced by perceived usefulness and perceived ease of use to adopt e-government services. The latter two are the fundamental TAM constructs of e-government services which are further affected by social influence, awareness of e-government services and quality of internet connection.

The results showed that the key constructs of TAM are validated in this study. Attitude ( $\beta$ $=0.57, \mathrm{p}<.05)$ and perceived usefulness $(\beta=0.28, \mathrm{p}<.05)$ all have a significant effect on the intention to adopt e-government services, similar to prior research (Hung et al., 2013; Lin et al, 2011; Sebetci, 2015), and found that the most important factors that affect intention to adopt e-government services, is attitude.

In accordance with previous studies (Hung et al., 2013; Lin et al, 2011; Sebetci, 2015), perceived ease of use is revealed as an important antecedent affecting perceived usefulness $(\beta=0.49, \mathrm{p}<.05)$ and attitude $(\beta=0.35, \mathrm{p}<.05)$, and the relationship between perceived ease of use and perceived usefulness is stronger than attitude towards adoption e-government services.

The results reveal also that social influence $(\beta=0.25, \mathrm{p}<.05)$ has a significant effect on the user's perceived usefulness to adopt e-government services. This result is consistent with previous studies (Lin et al, 2011) (Figure 2). 
Table 2. Results of rotated factor loading and composite reliability

\begin{tabular}{|c|c|c|c|}
\hline Constructs and Items & $\begin{array}{l}\text { Standardized } \\
\text { Loading }\end{array}$ & Cronbach Alpha & AVE \\
\hline Perceived usefulness of e-Government (PU) & & & \\
\hline $\begin{array}{l}\text { - PU1: Using the e-Government services would enable } \\
\text { me to accomplish my tasks more quickly. }\end{array}$ & .736 & \multirow{4}{*}{.870} & \multirow{4}{*}{.97} \\
\hline $\begin{array}{l}\text { - PU2: Using the e-Government would make it easier } \\
\text { for me to carry out my tasks. }\end{array}$ & .811 & & \\
\hline - PU3: I would find the e-Government services useful. & .691 & & \\
\hline $\begin{array}{l}\text { - PU4: Overall, I would find using the e-Government to } \\
\text { be advantageous. }\end{array}$ & .668 & & \\
\hline \multicolumn{4}{|l|}{ Perceived ease of use of e-Government (EOU) } \\
\hline - EOU1: Using the e-Government services is easy for me. & .580 & \multirow{4}{*}{.828} & \\
\hline $\begin{array}{l}\text { - EOU2: I find my interaction with the use of the } \\
\text { e-Government services clear and understandable. }\end{array}$ & .660 & & .93 \\
\hline $\begin{array}{l}\text { - EOU3: It is easy for me to become skilful at the use } \\
\text { of the e-Government }\end{array}$ & .665 & & \\
\hline $\begin{array}{l}\text { - EOU4: Overall, I find the use of the e-Government } \\
\text { services easy. }\end{array}$ & .736 & & \\
\hline \multicolumn{4}{|l|}{ Social influence (SI) } \\
\hline $\begin{array}{l}\text { - SI1: People who are important to me think that I } \\
\text { should use e-Government services. }\end{array}$ & .813 & & \\
\hline - SI2: My friends think I should use e-Government services. & .813 & .991 & .92 \\
\hline \multicolumn{4}{|l|}{$\begin{array}{l}\text { - SI3: People whose opinions that I value prefer that I } \\
\text { use e-Government services. }\end{array}$} \\
\hline \multicolumn{4}{|l|}{ Quality of Internet connection (QIC) } \\
\hline - QIC1: I have adequate access to Internet. & .601 & \multirow{2}{*}{.662} & \\
\hline - QIC2: My access to Internet is easy. & .526 & & .82 \\
\hline $\begin{array}{l}\text { - QIC3: Internet helps me access e-Government } \\
\text { services anytime. }\end{array}$ & 671 & & \\
\hline \multicolumn{4}{|l|}{ E-government awareness (AW) } \\
\hline $\begin{array}{l}\text { - AW1: I have sufficient information about } \\
\text { e-Government services }\end{array}$ & .597 & \multirow{2}{*}{.813} & \\
\hline $\begin{array}{l}\text { - AW2: I have sufficient information regarding use of } \\
\text { e-Government services. }\end{array}$ & .824 & & .86 \\
\hline $\begin{array}{l}\text { - AW3: I am well informed about the benefits of using } \\
\text { e-Government services }\end{array}$ & .764 & & \\
\hline \multicolumn{4}{|l|}{ Attitude (ATT) } \\
\hline - ATT1: Using e-Government and the internet is a good idea. & .73 & \multirow{2}{*}{.793} & .96 \\
\hline - ATT2: Using e-Government is a pleasant idea. & .787 & & \\
\hline - ATT3: Using e-Government is a positive idea. & .611 & & \\
\hline
\end{tabular}


Table 2. Continued

\begin{tabular}{|l|l|l|l|}
\hline \multicolumn{1}{|c|}{ Constructs and Items } & \multicolumn{1}{|c|}{$\begin{array}{c}\text { Standardized } \\
\text { Loading }\end{array}$} & Cronbach Alpha & AVE \\
\cline { 1 - 2 } Intention (INT) & \multicolumn{2}{|c|}{.852} & \\
\cline { 1 - 2 } $\begin{array}{l}\text { - INT1: I intend to continue using e-Government } \\
\text { services in the future }\end{array}$ & .725 & \multirow{2}{*}{.84} \\
\cline { 1 - 2 } $\begin{array}{l}\text { - INT2: I will always try to use e-Government services } \\
\text { in my daily life }\end{array}$ & .826 & & \\
\cline { 1 - 2 } $\begin{array}{l}\text { - INT2: I plan to continue to use e-Government } \\
\text { services frequently. }\end{array}$ & .767 & & \\
\hline
\end{tabular}

Table 3. Correlation matrix

\begin{tabular}{|l|l|l|l|l|l|l|l|}
\hline & \multicolumn{1}{|c|}{ PU } & \multicolumn{1}{c|}{ PEOU } & \multicolumn{1}{c|}{ ATT } & \multicolumn{1}{c|}{ SI } & \multicolumn{1}{c|}{ AW } & QIC & INT \\
\hline PU & 0.97 & & & & & & \\
\hline PEOU & 0.50 & 0.93 & & & & & \\
\hline ATT & 0.42 & 0.48 & 0.96 & & & & \\
\hline SI & 0.46 & 0.16 & 0.25 & 0.92 & & & \\
\hline AW & 0.41 & 0.26 & 0.42 & 0.36 & 0.86 & & \\
\hline QIC & 0.23 & 0.48 & 0.38 & 0.45 & 0.36 & 0.82 & \\
\hline INT & 038 & 0.26 & 0.51 & 053 & 0.56 & 054 & 0.84 \\
\hline
\end{tabular}

Notes: PU: Perceived usefulness; PEOU: perceived ease of use; ATT: Attitude; INT: Intention; SI: Social influence; AW: Awareness; QIS: Quality Internet Connection; The diagonal element represent the square of AVE (Average variance extracted)

Table 4. Fit indices for measurement and structural model

\begin{tabular}{|l|l|l|l|}
\hline \multicolumn{1}{|c|}{ Fit Indices } & \multicolumn{1}{|c|}{ Recommanded Value } & \multicolumn{1}{c|}{ Measurement Model } & \multicolumn{1}{c|}{ Structural Model } \\
\hline Chi squared of freedom & $\leq 3.00$ & 2.03 & 1.98 \\
\hline Normalized Fit Index (NFI) & $\geq 0.90$ & 0.90 & 0.92 \\
\hline $\begin{array}{l}\text { Non- Normalized Fit Index } \\
\text { (NNFI) }\end{array}$ & $\geq 0.90$ & 0.91 & 0.90 \\
\hline $\begin{array}{l}\text { Comparative Fit Index } \\
\text { (CFI) }\end{array}$ & $\geq 0.60$ & 0.91 & 0.91 \\
\hline $\begin{array}{l}\text { Goodness of Fit Index } \\
\text { (GFI) }\end{array}$ & $\geq 0.90$ & 0.92 & 0.96 \\
\hline $\begin{array}{l}\text { Adjusted goodness of Fit } \\
\text { (AGFI) }\end{array}$ & $\geq 0.80$ & 0.82 & 0.92 \\
\hline $\begin{array}{l}\text { Root mean square residual } \\
\text { (RMR) }\end{array}$ & $\leq 0.10$ & 0.072 & 0.091 \\
\hline $\begin{array}{l}\text { Root Mean Square Error of } \\
\text { Approximation (RMSEA) }\end{array}$ & $<0.08$ & 0.066 & 0.075 \\
\hline
\end{tabular}


Table 5. Path coefficients and hypothesis testing

\begin{tabular}{|l|l|l|l|l|l|}
\hline \multicolumn{1}{|c|}{ Hypothesis } & \multicolumn{1}{|c|}{ Relation } & $\begin{array}{c}\text { Hypothesized } \\
\text { Direction }\end{array}$ & $t$-Value & Path Coefficient & Supported \\
\hline H1 & ATT $\rightarrow$ INT & + & 2.94 & .57 & YES \\
\hline H2 & PU $\rightarrow$ INT & + & 2.83 & .28 & YES \\
\hline H3 & PU $\rightarrow$ ATT & + & 5.92 & .520 & YES \\
\hline H4 & PEOU $\rightarrow$ PU & + & 2.36 & .49 & YES \\
\hline H5 & PEOU $\rightarrow$ ATT & + & 3.26 & .35 & YES \\
\hline H6 & SI $\rightarrow$ PU & + & 5.38 & .24 & YES \\
\hline H7 & AW $\rightarrow$ PU & + & 3.28 & .23 & YES \\
\hline H8 & QIC $\rightarrow$ PEOU & + & 2.96 & .60 & YES \\
\hline
\end{tabular}

Figure 2. Results of the structural model

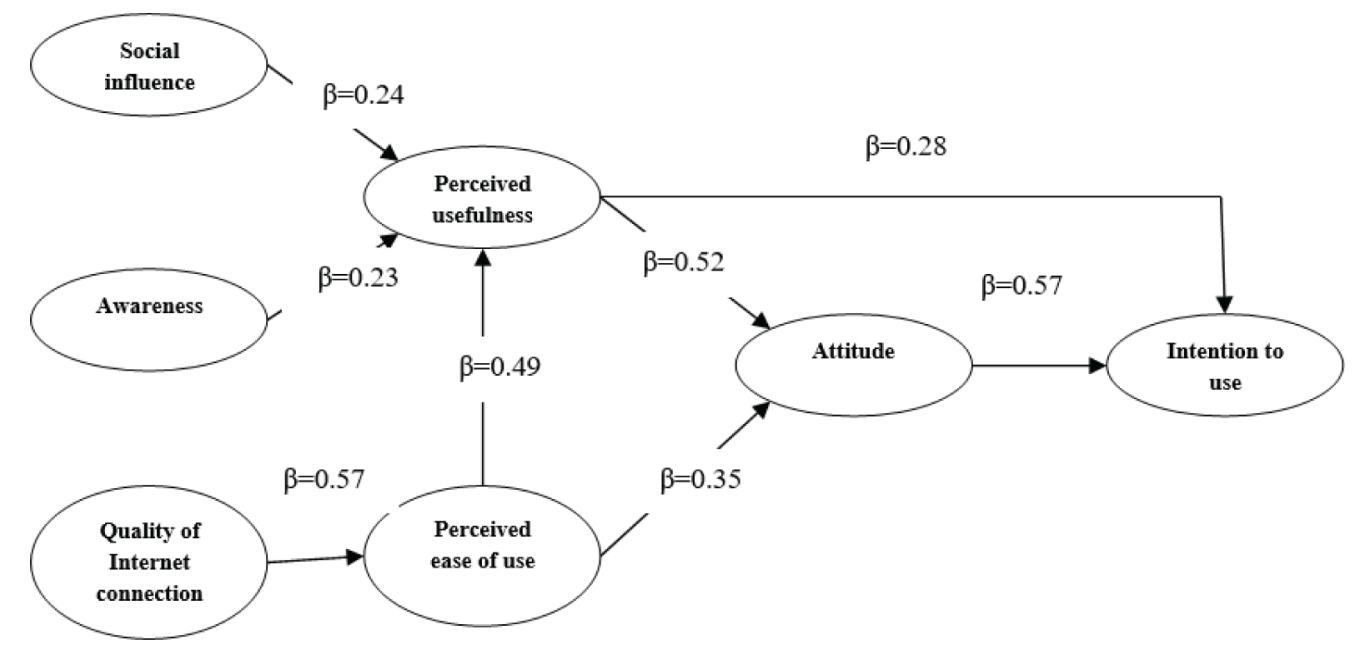

In addition, the results found that awareness $(\beta=0.20, \mathrm{p}<.05)$ has a positive effect on perceived usefulness to adopt e-government services, which is not empirically investigated in previous research. Finally, the results indicate that quality internet connection appears to be a significant and positive antecedent of perceived ease of use. Such results are in line with existing literature in the Internet banking area (Venkatesh \& Davis, 2002; Santo, 2003; Parasuraman et al. 1991).

\section{CONCLUSION, IMPLICATIONS, LIMITATION AND FUTURE RESEARCH}

This research has examined the factors that influence the behavioral intention of Tunisian citizen to adopt e-government services using Technology Acceptance Model (TAM) model. The contributions of this study have both theoretical and practical implications.

For theoretical implications, the study proposed a new model to identify determinants of behavioral intention to use e-Government services. At the same time, the study not only introduces social influence, awareness and quality of internet connection to the Technology Acceptance Model, but also the findings indicate that the proposed model is a stable model and a good explanatory, which contributes to the research of e-government adoption. 
Thus, this study is unique to the Tunisian context. Further, the study can be served as a starting point for other e-Government adoption researches in Tunisia. Moreover, it is the first study of e-Government services adoption that provides to the Tunisian government an empirical analysis, which is necessary for fostering adoption and usage e-government services by citizens. The extended TAM model can be used by future researchers for better analysis of e-government adoption.

For practical implications, determining the key success factors that influence behavioral intention to adopt e-government services would be useful for government in formulating policies and strategies to increase the adoption of e-government services in Tunisia as well as in other countries. For instance, they should implement policies and strategies that emphasise the usefulness, the ease of use, the attitude, social influence, awareness and quality of internet connection. For perceived usefulness and perceived ease of use, government should organize education and training program to make the citizens aware of e-government services. Government should also inform about different benefits of using e-government services. As people have higher degree of awareness of e-government services, they will use the services that the e-government services can provide.

The study has several limitations that affect the reliability and validity of the findings which will limit the ability to generalize them. First, the relatively small size of the sample limits generalization of the outcome of the study. Second, the study did not test the moderating effect of demographics that might affect the level of acceptance of e-government services. Further studies might use a more representative sample and including more variables in the extended model that might better explain the adoption of internet banking and/or information technology usage. It would also be worthwhile to test differences of demographics such as gender and educational level on the acceptance of internet banking. 


\section{REFERENCES}

Ajzen, I. (1991). The theory of planned behaviour. Organizational Behavior and Human Decision Processes, 50(2), 179-211. doi:10.1016/0749-5978(91)90020-T

Ajzen, I., \& Fishbein, M. (1975). Belief, attitude, intention, and behavior: an introduction to theory and research. Reading, MA: Addison Wesley.

Anderson, J. C., \& Gerbing, D. W. (1988). Structural equation modeling in practice: A review and recommended two-step approach. Psychological Bulletin, 103(3), 411-423. doi:10.1037/0033-2909.103.3.411

Atkinson, R. D., \& Castro, D. (2008). Digital quality of life: Understanding the personal and social benefits of the information technology revolution. ITIF.

Bagozzi, R. P., \& Yi, Y. (1988). On the evaluation of structural equation models. Journal of the academy of marketing science, 16(1), 74-94.

Chan, S. C., \& Lu, M. T. (2004). Understanding internet banking adoption and use behavior: A Hong Kong perspective. Journal of Global Information Management, 12(3), 21-43. doi:10.4018/jgim.2004070102

Chau, P. Y. K. (1996). An empirical assessment of a modified technology acceptance model. Journal of Management Information Systems, 13(2), 185-204. doi:10.1080/07421222.1996.11518128

Churchill, G. A. Jr. (1979). A paradigm for developing better measures of marketing constructs. JMR, Journal of Marketing Research, 16(1), 64-73. doi:10.1177/002224377901600110

Davis, F. D. (1989). Perceived usefulness, perceived ease of use, and user acceptance of information technology. Management Information Systems Quarterly, 13(3), 319-340. doi:10.2307/249008

Davis, F. D., Bagozzi, R. P., \& Warshaw, P. R. (1989). User acceptance of computer technology: A comparison of two theoretical models. Management Science, 35(8), 982-1003. doi:10.1287/mnsc.35.8.982

Davis, F. D., \& Venkatesh, V. (1996). A critical assessment of potential measurement biases in the technology acceptance model: Three experiments. International Journal of Human-Computer Studies, 45(1), 19-45. doi:10.1006/ijhc.1996.0040

Gefen, D., Straub, D., \& Boudreau, M. C. (2000). Structural equation modeling and regression: Guidelines for research practice. Communications of the Association for Information Systems, 4(7), 1-77.

Gupta, B., Dasgupta, S., \& Gupta, A. (2008). Adoption of ICT in a government organization in a developing country: An empirical study. The Journal of Strategic Information Systems, 17(2), 140-154. doi:10.1016/j. jsis.2007.12.004

Hair, F. J., Black, W., Babin, B., \& Anderson, R. (2010). Multivariate Data Analysis: A Global Perspective. NJ: Pearson Education.

Hwang, M. S., Li, C. T., Shen, J. J., \& Chu, Y. P. (2004). Challenges in e-government and security of information. Information \& Security, 15(1), 9e20.

Keil, M., Beranek, P. M., \& Konsynski, B. R. (1995). Usefulness and Ease of Use: Field Study Evidence Regarding Task Considerations. Decision Support Systems, 13(1), 75-91. doi:10.1016/0167-9236(94)E0032-M

Lin, F., Fofanah, S. S., \& Liang, D. (2011). Assessing citizen adoption of e-government initiatives in Gambia: A validation of the technology acceptance model in information systems success. Government Information Quarterly, 28(2), 271-279.

Miltgen, C. L., Popovič, A., \& Oliveira, T. (2013). Determinants of end-user acceptance of biometrics: Integrating the 'Big 3' of technology acceptance with privacy context. Decision Support Systems, 56, 103-114. doi:10.1016/j. dss.2013.05.010

Nunnally, J. C. (1978). Psychometric Theory (Vol. 2). New York, NY: McGraw-Hill.

Parasuraman, A., Berry Leonard, L., \& Zeithmal, V. A. (1991). Refinement and reassessment of the servequal scale. Journal of Retailing, 67(4), 420-450. 
Reffat, R. (2003). Developing a successful e-government. In Proc. Sympos. e-Government: Opportunities and Challenge, Muscat Municipality, Oman (pp. IV1eIV13).

Rogers, E. M., \& Shoemaker, F. F. (1971). Communication of innovations: A cross-cultural approach. New York: The Free Press.

Santos, J. (2003). E-Service quality: A model of virtual service quality dimension. Managing Service Quality, 13(3), 233-246. doi:10.1108/09604520310476490

Sathye, M. (1999). Adoption of Internet banking by Australian consumers: An empirical investigation. International Journal of Bank Marketing, 17(7), 324-334. doi:10.1108/02652329910305689

Sebetci, Ö. (2015). A TAM-based model for e-government: A case for Turkey. International Journal of Electronic Governance, 7(2), 113-135. doi:10.1504/IJEG.2015.069503

Shih, Y., \& Fang, K. (2004). The use of a decomposed theory of planned behavior to study internet banking in Taiwan. Internet Research, 14(3), 213-223. doi:10.1108/10662240410542643

Titah, R., \& Barki, H. (2006). E-Government Adoption and Acceptance: A Literature Review. International Journal of Electronic Government Research, 2(3), 23-57. doi:10.4018/jegr.2006070102

Venkatesh, V., \& Davis, F. D. (1996). A model of antecedents of perceived ease of use: Development and test. Decision Sciences, 27(3), 451-481. doi:10.1111/j.1540-5915.1996.tb01822.x

Venkatesh, V., \& Davis, F. D. (2000). A Theoretical extension of the technology acceptance model: Four longitudinal field studies. Management Science, 46(2), 186-204. doi:10.1287/mnsc.46.2.186.11926

Venkatesh, V., Morris, M. G., Davis, G. B., \& Davis, F. D. (2003). User acceptance of information technology: Toward a unified view. Management Information Systems Quarterly, 27(3), 425-478. doi:10.2307/30036540 


\section{APPENDIX}

Table 6. Measurement items adopted

\begin{tabular}{|c|c|c|}
\hline Constructs & Question Description & References \\
\hline \multirow{4}{*}{$\begin{array}{l}\text { Perceived usefulness of } \\
\text { e-Government (PU) }\end{array}$} & $\begin{array}{l}\text { - PU1: Using the e-Government services would enable me to accomplish my tasks more } \\
\text { quickly. }\end{array}$ & \multirow{4}{*}{ Davis et al. (1989) } \\
\hline & - PU2: Using the e-Government would make it easier for me to carry out my tasks. & \\
\hline & - PU3: I would find the e-Government services useful. & \\
\hline & $\begin{array}{l}\text { PU4: Overall, I would find using the e-Government to be } \\
\text { - advantageous. }\end{array}$ & \\
\hline \multirow{4}{*}{$\begin{array}{l}\text { Perceived ease of use of } \\
\text { e-Government (EOU) }\end{array}$} & - EOU1: Using the e-Government services is easy for me. & \multirow{4}{*}{ Davis et al. (1989) } \\
\hline & $\begin{array}{l}\text { - EOU2: I find my interaction with the use of the e-Government services clear and } \\
\text { understandable. }\end{array}$ & \\
\hline & $\begin{array}{l}\text { - EOU3: It is easy for me to become skilful at the use of the } \\
\text { - e-Government. }\end{array}$ & \\
\hline & - EOU4: Overall, I find the use of the e-Government services easy. & \\
\hline \multirow{3}{*}{ Social influence (SI) } & $\begin{array}{l}\text { - SI1: People who are important to me think that I should use } \\
\text { - e-Government services. }\end{array}$ & \multirow{3}{*}{ Venkatesh et al. (2012) } \\
\hline & - SI2: My friends think I should use e-Government services. & \\
\hline & $\begin{array}{l}\text { - SI3: People whose opinions that I value prefer that I use } \\
\text { - e-Government services. }\end{array}$ & \\
\hline \multirow{4}{*}{$\begin{array}{l}\text { Quality of Internet } \\
\text { connection (QIC) }\end{array}$} & - QI1: I have adequate access to Internet. & \multirow{4}{*}{$\begin{array}{l}\text { Pikkarainen et al. } \\
(2004)\end{array}$} \\
\hline & - QI2: My access to Internet is easy. & \\
\hline & - QI3: My Internet helps me to finish e-Government services correctly. & \\
\hline & - QI4: Internet helps me access e-Government services anytime. & \\
\hline \multirow{4}{*}{$\begin{array}{l}\text { Internet banking awareness } \\
\text { (IBA) }\end{array}$} & - AW1: I have sufficient information about e-Government services & \multirow{4}{*}{ Sathye (1999) } \\
\hline & $\begin{array}{l}\text { - AW2: I have sufficient information regarding various services } \\
\text { - offered by e-Government. }\end{array}$ & \\
\hline & $\begin{array}{l}\text { - AW3: I have sufficient information regarding use of } \\
\text { - e-Government services }\end{array}$ & \\
\hline & $\begin{array}{l}\text { - AW4: I am well informed about the benefits of using } \\
\text { - e-Government services }\end{array}$ & \\
\hline \multirow{3}{*}{ Attitude (ATT) } & - ATT1: Using e-Government and the internet is a good idea. & \multirow{3}{*}{ Venkatesh et al. (2003) } \\
\hline & - ATT2: Using e-Government is a pleasant idea. & \\
\hline & - ATT3: Using e-Government is a positive idea. & \\
\hline \multirow{3}{*}{ Intention (INT) } & - INT1: I intend to continue using e-Government services in the future & \multirow{3}{*}{ Venkatesh et al. (2012) } \\
\hline & - INT2: I will always try to use e-Government services in my daily life & \\
\hline & - INT2: I plan to continue to use e-Government services frequently. & \\
\hline
\end{tabular}

Wadie Nasri is an Associate Professor in Competitive Intelligence and Marketing in the Higher Institute of Management, University of Gabes. He received his philosophy doctorate in marketing intelligence from the Faculty of Economic Sciences and Management, University of Tunis Al-Manar. His current research interests are in the fields of marketing information system, competitive intelligence, strategy, management, electronic commerce, information technology adoption, internet banking adoption, and e-government adoption. 